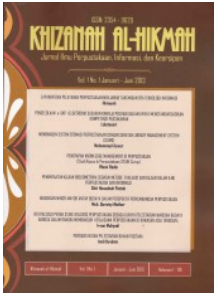

\title{
STUDI KORELASI PESAN PENAGIHAN KOLEKSI PERPUSTAKAAN MELALUI WHATSAPP DENGAN SIKAP PEMUSTAKA TERHADAP SANKSI ADMINISTRATIF
}

\author{
Aulia Asmayanti*, Prijana*, Andri Yanto*
}

Pengutipan: Asmayanti, A., Prijana., Yanto, A. (2018). Studi korelasi pesan penagihan koleksi perpustakaan melalui whatsapp dengan sikap pemustaka terhadap sanksi administratif. Khizanah al-Hikmah : Jurnal Ilmu Perpustakaan, Informasi, dan Kearsipan, 6(1), 41-54.

DOI: $10.24252 /$ kah.v6a1a5

\author{
*Universitas Padjajaran, Bandung \\ auliasmayanti@gmail.com,prijana@unpad.ac.id, andri.yanto@unpad.ac.id
}

\begin{abstract}
ABSTRAK
Tujuan penelitian ini adalah untuk mengetahui hubungan pesan penagihan koleksi melalui media sosial dengan sikap pemustaka terhadap sanksi administratif perpustakaan, dengan menguji hubungan intensitas, isi pesan, dan daya tarik pesan dengan penghindaran sanksi administratif Perpustakaan Kemendikbud. Metode yang digunakan adalah studi korelasi dengan pendekatan kuantitatif. Populasi penelitian ini adalah anggota Perpustakaan Kemendikbud yang menerima pesan penagihan koleksi periode April - Juli 2017. Penelitian ini menggunakan sampel total sebanyak 85 orang. Teori yang digunakan dalam penelitian ini adalah teori uses and effect dan konsep terpaan media. Teknik analisis uji korelasi menggunakan pearson product moment. Hasil penelitian menunjukkan bahwa intensitas pesan berhubungan signifikan dengan penghindaran sanksi administratif, isi pesan tidak berhubungan signifikan dengan penghindaran sanksi administratif, daya tarik pesan berhubungan signifikan dengan penghindaran sanksi administratif.
\end{abstract}

Kata kunci: Pesan penagihan koleksi; whatsapp; teori uses dan gratifikasi

\section{ABSTRACT}

This study aims to find the correlation of collection notification messages with user's attitude to administrative sanction, by testing the correlation of intensity, message's content, and message's attraction through whatsapp by avoidance of administrative sanctions. This research uses quantitative approach with case study correlation method. Population of this research are Kemendikbud's Library member that already received invoice message since April July 2017. This research using total sample about 85 people. This research use uses and effet theory and also media exposure concept. The correlation analysis technique using pearson product moment. The result of this research concludes intensity has significant correlation with avoidance of administrative sanctions, message has no significant correlation with avoidance of administrative sanctions, and message's attraction has significant correlation with avoidance of administrative sanctions.

Keywords: library's invoice message; whatsapp; uses and gratification theory

\section{PENDAHULUAN}

\section{a. Latar Belakang Masalah}

Perpustakaan sebagai sumber informasi yang menyimpan koleksi bahan pustaka bertujuan untuk melayani dan memenuhi kebutuhan masyarakat akan kebutuhan informasi. Kebutuhan akan informasi yang banyak dan juga dengan waktu peminjaman yang terbatas membuat terjadinya perilaku unauthorized 
borrowing. Unauthorized borrowing atau peminjaman tidak sah merupakan kegiatan pemustaka yang melanggar ketentuan peminjaman (Obigawu, 1992).

Perilaku unauthorized borrowing yang terjadi di perpustakaan berdampak pada berkurangnya koleksi yang ada di perpustakaan yang menyebabkan kurangnya koleksi yang bisa dibaca di tempat ataupun dipinjam oleh pemustaka lain. Salah satu bentuk perilaku unauthorized borrowing adalah keterlambatan waktu pengembalian koleksi perpustakaan. Untuk itu dibutuhkan upaya untuk mengurangi tindakan ini, yaitu dengan menerapkan pencegahan sebagai cara untuk meningkatkan kedisiplinan pemustaka melalui cara-cara yang dipilih oleh perpustakaan.

Dalam upaya pencegahan tindak keterlambatan pengembalian koleksi oleh pemustaka, Perpustakaan Kemendikbud melaksanakan layanan pengiriman surat peringatan penagihan koleksi serta adanya sanksi administratif un bagi pemustaka yang melanggar. Pengiriman pesan penagihan dilakukan melalui akun media sosial whatsapp Perpustakaan Kemendikbud. Selain memudahkan komunikasi jarak jauh, kehadiran media sosial memberikan begitu banyak kemudahan, mulai dari mudahnya bertukar pesan dan informasi, sampai pada kemudahan seorang pemustaka yang ingin mempublikasikan karyanya agar dapat diketahui orang lain, menghilangkan batasan generasi dan memperluas wacana yang dapat dipertukarkan (Rusmana, 2015).

Penggunaan media sosial whatsapp dalam pengiriman pesan penagihan koleksi perpustakaan menggantikan caracara sebelumnya berupa pengiriman surat dan e-mail. Pengiriman pesan penagihan melalui whatsapp ini dikirim secara personal kepada pemustaka yang terlambat mengembalikan koleksi.

Menurut survei We Are Sosial, yang menemukan bahwa media sosial whatsapp berada di urutan ketiga yaitu sebesar $14 \%$ berdasarkan peringkat penggunaan aktif media sosial di Indonesia. Maka benar dan baik ketika Perpustakaan Kemendikbud memilih memanfaatkan media sosial dalam proses layanannya, khususnya pengiriman pesan penagihan. Selain itu, manfaat dari media sosial bagi perpustakaan menurut Kurniasih (2015) yaitu, menghemat waktu dan biaya penyebaran informasi, memberikan akses layanan perpustakaan yang lebih luas dan cepat, dan mendapatkan umpan balik secara langsung lebih cepat.

Pengiriman pesan secara personal dari admin perpustakaan kepada pemustaka diharapkan dapat memunculkan respon atau umpan balik yang cepat. Penggunaan media sosial ini memungkinkan pemustaka dapat segera mengembalikan atau memperpanjang peminjaman dan mematuhi peraturan perpustakaan sebagai bentuk sikap pemustaka terhadap tata tertib perpustakaan bagi pemustaka.

Maka peneliti tertarik untuk melihat apakah pesan penagihan koleksi melalui media sosial berhubungan dengan sikap pemustaka terhadap tata tertib Perpustakaan Kementerian Pendidikan dan Kebudayaan Republik Indonesia

\section{b. Rumusan Masalah}

Permasalahan dalam penelitian ini dapat diidentifikasi sebagai berikut:

1) Apakah intensitas pesan-pesan penagihan koleksi melalui media sosial whatsapp memiliki hubungan 
signifikan dengan sikap pemustaka terhadap sanksi administratif?

2) Apakah isi pesan penagihan koleksi melalui media sosial whatsapp memiliki hubungan signifikan dengan sikap pemustaka terhadap sanksi administratif?

3) Apakah daya tarik pesan penagihan koleksi melalui media sosial whatsapp memiliki hubungan signifikan dengan sikap pemustaka terhadap sanksi administratif?

\section{TINJAUAN LITERATUR}

Teori uses and effect merupakan hasil sintesis dari teori uses and gratifications dan teori tradisional terkait efek yang dikemukakan oleh Windahl (1979). Konsep 'use' atau penggunaan adalah bagian yang penting dan pokok dalam pemikiran ini. Teori ini menganggap bahwa kebutuhan hanya salah satu faktor penyebab terjadinya penggunaan media di mana karakteristik individu, harapan dan persepsi terhadap media, dan tingkat akses kepada media menjadi keputusan individu untuk menggunakan atau tidak menggunakan isi media massa (Sendjadja, 2007).

Berdasarkan penjabaran di atas, model yang digunakan dalam penelitian ini adalah model uses and effect yang pertama kali dikenalkan oleh Sven Windahl tahun 1979. Teori uses and effect memiliki asumsi dasar bahwa penggunaan media menghasilkan banyak efek terhadap suatu individu (Sendjadja, 2002). Namun perbedaannya adalah media yang digunakan merupakan media sosial whatsapp yang mengirimkan pesan penagihan koleksi secara broadcast atau serentak. Di mana isi pesan dan penggunaan media sosial whatsapp memiliki pengaruh terhadap sikap penerimanya. Hubungan yang terdapat dalam teori ini adalah bagaimana isi media menjadikan alasan penggunaan media yang selanjutnya menghasilkan efek dari penggunaan media tersebut. Penggunaan media whatsapp sebagai media atau saluran penyampaian pesan menghasilkan efek sebagai respon dari pesan tersebut. Penggunaan media sosial sendiri memiliki tiga indikator dalam penilaiannya, yaitu intensitas, isi pesan, dan daya tarik (Liliweri, 1992).

Penerapan intensitas di sini adalah bagaimana intensitas penggunaan media sosial whatsapp dan intensitas pengiriman serta penerimaan pesan penagihan koleksi dari Perpustakaan Kemendikbud untuk anggota Perpustakaan Kemendikbud menghasilkan efek berupa sikap.

Indikator kedua adalah isi pesan. Isi pesan terdiri dari kelengkapan pesan, kejelasan pesan dan penggunaan tata bahasa yang digunakan. Indikator ketiga adalah daya tarik. Daya tarik dalam penelitian ini adalah daya tarik pesan penagihan koleksi yang dikirim menggunakan akun whatsapp Perpustakaan Kemendikbud. Penggunaan jenis media seharusnya dipilih menurut jenis pesan yang dikirim, banyaknya pemakai dan intensitas pemakaian media tersebut. Jenis pesan yang dikirim adalah berupa teks pesan penagihan dengan media pengiriman media elektronik berupa media sosial whatsapp. Media ini dipilih karena jumlah anggota perpustakaan yang menggunakan media sosial whatsapp cukup tinggi di antara media sosial lainnya. Sehingga diharapkan penggunaan media sosial whatsapp akan lebih efektif.

Ketiga indikator penggunaan media tersebut akan menghasilkan efek berupa sikap dari pemustaka atas pesan 
penagihan keterlambatan yang mereka terima. Sikap merupakan semacam kesiapan untuk bereaksi terhadap suatu objek dengan cara-cara tertentu (Chave dkk dalam Azwar, 2012). Untuk merubah sikap dibutuhkan cara-cara yang sesuai dengan kebutuhan dan kemampuan serta dengan bantuan media. Penggunaan media tersebut akan menghasilkan efek. Perubahan sikap salah satunya dapat terjadi karena kekuatan-kekuatan pendorong meningkat karena adanya stimulus-stimulus yang mendorong untuk terjadinya perubahan-perubahan. Stimulus di sini adalah informasi atau pesan penagihan keterlambatan koleksi yang diterima oleh anggota perpustakaan. Dengan adanya pesan tersebut akan dilihat bagaimana afeksi, kognisi, dan perilaku anggota terhadap pesan penagihan koleksi yang dikirim secara personal menggunakan media sosial whastsapp terhadap sanksi administratif perpustakaan.

\section{METODOLOGI PENELITIAN}

\section{a. Metode Penelitian}

Penelitian ini menggunakan pendekatan kuantitatif dengan metode korelasional. Metode ini merupakan kelanjutan dari metode deskriptif, di mana peneliti menghimpun data, menyusun secara sistematis, faktual dan cermat dan kemudian menjelaskan hubungan di antara dua variabel, menguji hipotesis dan melakukan prediksi (Rakhmat, 1991: 27). Tujuan pemakaian metode korelasional dalam penelitian ini adalah untuk mencari dan meneliti hubungan antara variabel dengan tujuan akhir melihat korelasi pengaruh antar variabel.

\section{b. Populasi dan Sampel}

Populasi penelitian ini adalah anggota Perpustakaan Kemendikbud yang menerima pesan penagihan. Penelitian ini mengambil total unit populasi yaitu anggota yang mendapatkan pesan penagihan koleksi sejak April 2017-Juli 2017 yang berjumlah 95 anggota sebagai responden penelitian. Sampling adalah proses untuk mendapatkan sampel dari suatu populasi. Di sini sampel harus benar-benar mencerminkan populasi, karena hakikatnya yang kecil itu mencerminkan yang besar, yang sedikit itu mencerminkan yang banyak (Prijana, Winoto dan Yanto, 2016). Lebih lanjut menurut Surakhmad (1978) dalam Bungin (2004), sampel penelitian tidak diperlukan ketika penelitian kuantitatif dilakukan terhadap objek atau populasi yang kecil, objek penelitian yang kecil ini disebut sampel total yaitu keseluruhan populasi yang merangkap sebagai sampel penelitian.

Peneliti menyebarkan kuisioner ke 95 orang responden yang merupakan ukuran populasi, namun dalam pelaksanaannya kuesioner yang kembali adalah sebanyak 85 kuesioner. Kuesioner disebar secara online dengan mengirimkan link kuisioner online secara personal ke 95 responden dan juga secara manual.

\section{c. Teknik Pengumpulan Data}

Teknik pengumpulan data dilakukan dengan penyebaran kuisioner secara langsung dan online, observasi serta wawancara.

\section{d. Teknik Analisis Data}

Untuk mengetahui apakah populasi data berdistribusi normal atau tidak, peneliti menggunakan uji normalitas menggunakan metode Kolmogorov- 
Smirnov. Data dikatakan berdistribusi normal apabila pada tabel test of normality menggunakan KolmogorovSmirnov nilai hitung $>$ nilai tabel $(0,145)$ dengan $\mathrm{N}$ sebesar 85 .

\begin{tabular}{|l|r|}
\hline & \multicolumn{2}{|c|}{$\begin{array}{c}\text { Unstandardized } \\
\text { Rsidual }\end{array}$} \\
\hline Absolute & .096 \\
\hline Positive & .033 \\
\hline
\end{tabular}

\section{e. Teknik Analisis Data}

Analis data deskriptif dalam penelitian ini dilakukan untuk menggambarkan data yang diperoleh mengenai pesan penagihan koleksi perpustakaan melalui media sosial koleksi dengan sikap pemustaka terhadap sanksi administratif melalui media sosial whatsapp menggunakan uji frekuensi dan Chi-Square.

Analisis korelasional adalah analisis statistik yang berusaha untuk mencari hubungan antara dua variabel. Uji korelasi penelitian ini menggunakan analisis pearson product moment menggunakan software SPSS versi 22 . Analisis korelasi pearson product moment bertujuan untuk menganalisis hubungan sebab-akibat antara variabel independen dengan variabel dependen.

\section{HASIL PENELITIAN PEMBAHASAN}

Uji hipotesis penelitian dilakukan untuk melihat signifikansi hubungan antar variabel penelitian. Pengujian hipotesis yang dilakukan dalam penelitian ini adalah pada variabel bebas $(X)$ pesan penagihan koleksi perpustakaan dan variabel terikat (variabel Y) sikap pemustaka terhadap sanksi administratif.
Uji hipotesis dilakukan dengan menggunakan uji $t$ dengan $a=0.05$ untuk uji dua pihak (two tail test), dengan ketentuan sebagai berikut:

- $t_{\text {hitung }} \geq \mathrm{t}_{\text {tabel }}$ maka $\mathrm{H}_{0}$ ditolak dan signifikan.

- $t_{\text {hitung }} \leq \mathrm{t}_{\text {tabel }}$ maka $\mathrm{H}_{0}$ diterima dan tidak signifikan. (Siregar, 2011, 156).

Setelah menguji hipotesis, selanjutnya dilakukan interpretasi data dengan menggunakan tabel intepretasi nilai $r$.

Tabel 1. Interpretasi nilai $\mathrm{r}$

\begin{tabular}{|c|c|}
\hline Interval Koefisien & Tingkat Hubungan \\
\hline $0.800-1.000$ & Sangat Kuat \\
\hline $0.600-0.799$ & Kuat \\
\hline $0.400-0.599$ & Cukup Kuat \\
\hline $0.200-0.399$ & Rendah \\
\hline $0.000-0.199$ & Sangat Rendah \\
\hline
\end{tabular}

Sumber: Riduwan dan Sunarto, 2012

\section{a. Hasil Penelitian}

Berikut pemaparan hasil dan pembahasan dari penelitian ini.

$\mathrm{H}_{0} \quad$ : Intensitas pesan penagihan koleksi perpustakaan melalui media sosial whatsapp tidak berhubungan signifikan dengan sikap sikap pemustaka terhadap sanksi administratif.

$\mathrm{H}_{1} \quad$ : Intensitas pesan penagihan koleksi perpustakaan melalui media sosial whatsapp berhubungan signifikan dengan sikap sikap pemustaka terhadap sanksi administratif. 
Tabel 2. Hubungan intensitas pesan penagihan koleksi melalui media sosial dengan sikap pemustaka terhadap sanksi administratif

\begin{tabular}{|l|l|l|l|l|l|l|}
\hline $\begin{array}{l}\mathrm{Hu} \\
\text { b. }\end{array}$ & $\begin{array}{l}\mathrm{r}_{\text {hitu }} \\
\mathrm{ng}\end{array}$ & $\mathrm{r}^{2}$ & $\begin{array}{l}\mathrm{t}_{\text {hitu }} \\
\mathrm{ng}\end{array}$ & $\mathrm{t}_{\text {tabel }}$ & $\begin{array}{l}\text { Strength } \\
\text { of } \\
\text { Correlati } \\
\text { on }\end{array}$ & $\begin{array}{l}\text { Keputus } \\
\text { an }\end{array}$ \\
\hline $\begin{array}{l}\mathrm{X}_{1} \\
\leftrightarrow\end{array}$ & $\begin{array}{l}0,22 \\
\mathrm{Y}\end{array}$ & 0,05 & 2,11 & $\begin{array}{l}1,66 \\
3\end{array}$ & Rendah & $\begin{array}{l}\mathrm{H}_{0} \\
\text { ditolak }\end{array}$ \\
\hline
\end{tabular}

Berdasarkan hasil analisis di atas, dapat disimpulkan bahwa sub variabel independen (X1) yaitu intensitas pesan penagihan koleksi melalui akun whatsapp Perpustakaan

Kemendikbud berhubungan signifikan dengan variabel dependen (Y) yaitu sikap pemustaka terhadap tata tertib perpustakaan. Hasil uji korelasi dengan menggunakan uji person product moment menunjukkan koefisien korelasi sebesar 0,225 maka intepretasi koefisien korelasinya termasuk dalam tingkat hubungan rendah.

$\mathrm{H}_{0} \quad$ : $\quad$ Isi pesan penagihan koleksi melalui media sosial whatsapp tidak berhubungan signifikan dengan sikap pemustaka terhadap sanksi administratif.

$\mathrm{H}_{1} \quad$ : $\quad$ Isi pesan penagihan koleksi melalui media sosial whatsapp berhubungan signifikan dengan sikap pemustaka terhadap sanksi administratif.

Tabel 1 hubungan isi pesan penagihan koleksi melalui media sosial dengan sikap pemustaka terhadap sanksi administratif

\begin{tabular}{|l|l|l|l|l|l|l|}
\hline $\begin{array}{l}\mathrm{Hu} \\
\mathrm{b}\end{array}$ & $\begin{array}{l}\mathrm{r}_{\text {hitu }} \\
\mathrm{ng}\end{array}$ & $\mathrm{r}^{2}$ & $\begin{array}{l}\mathrm{t}_{\text {hitu }} \\
\mathrm{ng}\end{array}$ & $\mathrm{t}_{\text {tabel }}$ & $\begin{array}{l}\text { Strength } \\
\text { of } \\
\text { Correlati } \\
\text { on }\end{array}$ & $\begin{array}{l}\text { Keputus } \\
\text { an }\end{array}$ \\
\hline $\begin{array}{l}\mathrm{X}_{2} \\
\leftrightarrow\end{array}$ & $\begin{array}{l}0,07 \\
\mathrm{Y}\end{array}$ & $\begin{array}{l}0,00 \\
6\end{array}$ & 0,69 & $\begin{array}{l}1,66 \\
3\end{array}$ & $\begin{array}{l}\text { Sangat } \\
\text { Rendah }\end{array}$ & $\begin{array}{l}\mathrm{H}_{0} \\
\text { diterima }\end{array}$ \\
\hline
\end{tabular}

Berdasarkan hasil analisis di atas, dapat disimpulkan bahwa sub variabel independen (X1) yaitu isi pesan penagihan koleksi melalui akun whatsapp Perpustakaan Kemendikbud tidak berhubungan signifikan dengan variabel dependen (Y) yaitu sikap pemustaka terhadap tata tertib perpustakaan. Namun masih terdapat hubungan antara isi pesan penagihan koleksi dengan sikap menghindari sanksi administratif atau sikap pemustaka terhadap tata tertib perpustakaan oleh anggota yang menerima pesan penagihan tersebut. Hasil uji korelasi dengan menggunakan uji person product moment menunjukkan koefisien korelasi sebesar 0,076 maka interpretasi koefisien korelasinya termasuk dalam tingkat hubungan sangat rendah.

$\mathrm{H}_{0} \quad$ : Daya tarik media sosial whatsapp dalam pesan penagihan koleksi perpustakaan melalui media sosial tidak berhubungan signifikan dengan sikap sikap pemustaka terhadap sanksi administratif.

$\mathrm{H}_{1}$ : Daya tarik media sosial whatsapp dalam pesan penagihan koleksi perpustakaan melalui media sosial tidak berhubungan signifikan dengan sikap sikap pemustaka terhadap sanksi administratif.

Tabel 4. Hubungan daya tarik pesan penagihan koleksi melalui media sosial dengan sikap pemustaka terhadap sanksi administratif

\begin{tabular}{|c|c|c|c|c|c|c|}
\hline $\begin{array}{c}\mathrm{Hu} \\
\mathrm{b}\end{array}$ & $\begin{array}{c}\mathrm{r}_{\text {hitu }} \\
\mathrm{ng}\end{array}$ & $\mathrm{r}^{2}$ & $\begin{array}{l}\mathrm{t}_{\text {hit }} \\
\text { ung }\end{array}$ & $t_{\text {tabel }}$ & $\begin{array}{c}\text { Strength } \\
\text { of } \\
\text { Correlati } \\
\text { on }\end{array}$ & $\begin{array}{l}\text { Keputus } \\
\text { an }\end{array}$ \\
\hline $\begin{array}{c}\mathrm{X}_{3} \\
\leftrightarrow \\
\mathrm{Y}\end{array}$ & $\begin{array}{c}0,07 \\
6\end{array}$ & 0,006 & $\begin{array}{r}0 \\
69\end{array}$ & 1,663 & $\begin{array}{l}\text { Sangat } \\
\text { Rendah }\end{array}$ & $\begin{array}{c}\mathrm{H}_{0} \\
\text { diterima }\end{array}$ \\
\hline
\end{tabular}


Berdasarkan hasil analisis di atas, dapat disimpulkan bahwa sub variabel independen (X3) yaitu daya tarik pesan penagihan koleksi melalui akun whatsapp Perpustakaan

Kemendikbud berhubungan signifikan dengan variabel dependen $(\mathrm{Y})$. Hasil uji korelasi dengan menggunakan uji person product moment menunjukkan koefisien korelasi sebesar 0,655 maka interpretasi koefisien korelasinya termasuk dalam tingkat hubungan kuat.

\section{b. Pembahasan Penelitian}

Tabel 5. Jenis kelamin dengan frekuensi menerima pesan penagihan koleksi dari setiap peminjaman

\begin{tabular}{|c|c|c|c|c|c|c|c|}
\hline & \multicolumn{5}{|c|}{$\begin{array}{l}\text { Selalu menerima pesan } \\
\text { penagihan koleksi dari setiap } \\
\text { peminjaman }\end{array}$} & \multirow[b]{2}{*}{ Total } \\
\hline & & $\begin{array}{c}\text { Sanga } \\
\mathrm{t} \\
\text { tidak } \\
\text { setuju }\end{array}$ & $\begin{array}{c}\text { Tida } \\
\text { k } \\
\text { setu } \\
\text { ju }\end{array}$ & $\begin{array}{l}\mathrm{N} \\
\mathrm{e} \\
\mathrm{t} \\
\mathrm{r} \\
\mathrm{a} \\
\mathrm{l}\end{array}$ & $\begin{array}{l}\text { Se } \\
\text { tuj } \\
\mathrm{u}\end{array}$ & $\begin{array}{l}\text { San } \\
\text { gat } \\
\text { set } \\
\text { uju }\end{array}$ & \\
\hline \multirow{2}{*}{$\begin{array}{l}\text { Jeni } \\
\mathrm{s} \\
\text { Kel } \\
\text { ami } \\
\mathrm{n}\end{array}$} & $\begin{array}{l}\mathrm{La} \\
\mathrm{ki}- \\
\mathrm{La} \\
\mathrm{ki}\end{array}$ & 5 & 6 & 3 & 4 & 2 & 20 \\
\hline & $\begin{array}{l}\text { Per } \\
\text { em } \\
\text { pu } \\
\text { an }\end{array}$ & 6 & 19 & 6 & 33 & 1 & 65 \\
\hline \multicolumn{2}{|c|}{ Total } & 11 & 25 & 9 & 37 & 3 & 85 \\
\hline
\end{tabular}

Berdasarkan tabel 5, tanggapan responden terhadap frekuensi menerima pesan penagihan koleksi dari setiap peminjaman menunjukkan bahwa dari 85 responden terdapat 11 responden menyatakan sangat tidak setuju, 25 responden menyatakan tidak setuju, 9 responden menyatakan netral, 37 responden menyatakan setuju, dan 3 responden menyatakan sangat setuju. Dominasi tanggapan responden adalah dari responden berjenis kelamin wanita yang menyatakan setuju bahwa responden selalu menerima pesan penagihan koleksi dari setiap peminjaman koleksi. Dapat dikatakan bahwa responden dalam penelitian ini mendapatkan pesan penagihan koleksi dari setiap peminjaman koleksi.

Tabel 6. Hasil Uji Chi-Kuadrat

\begin{tabular}{|l|r|r|r|}
\hline & \multicolumn{1}{|c|}{ Value } & df & $\begin{array}{r}\text { Asymp. Sig. } \\
\text { (2-sided) }\end{array}$ \\
\hline $\begin{array}{l}\text { Pearson Chi- } \\
\text { Square }\end{array}$ & 9.852 & 4 & .043 \\
\hline Likelihood Ratio & 9.414 & 4 & .052 \\
\hline $\begin{array}{l}\text { Linear-by-Linear } \\
\text { Association }\end{array}$ & 2.323 & 1 & .127 \\
\hline N of Valid Cases & 85 & & \\
\hline \multicolumn{1}{|c|}{$\chi^{2}=9,85$} \\
\hline
\end{tabular}

Dari tabel 6, hasil uji Chi-Kuadrat antara jenis kelamin dengan frekuensi menerima pesan menunjukkan $\alpha=0,5$ dengan derajat kepercayaan $95 \%$ dan $\mathrm{df}=$ 4, Chi-kuadrat tabel sebesar 9,49 dan Chikuadrat hitung sebesar 9,85. Dengan demikian Chi-kuadrat hitung 9,85 > 9,49 Chi-kuadrat tabel. Maka terdapat hubungan antara jenis kelamin dengan frekuensi menerima pesan.

Untuk mengetahui derajat hubungan antara jenis kelamin dengan frekuensi menerima pesan menggunakan koefisien kontingensi C menggunakan rumus (Sudjana, 2005):

$$
C=\sqrt{\frac{m-1}{m}}
$$

Untuk menilai derajat asosiasi antar data, nilai $\mathrm{C}$ disbandingkan dengan nilai C maksimum (Cmaks). Untuk memperoleh nilai Cmaks menggunakan rumus: 


$$
C_{m a k s}=\sqrt{\frac{m-1}{m}}
$$

Diketahui nilai Chi-kuadrat hitung sebesar 9,85. Untuk memperoleh nilai koefisien kontingernsi $\mathrm{C}$ maksimum adalah dengan:

$$
\begin{aligned}
& C=\sqrt{\frac{X^{2}}{X^{2}+n}} \\
& C=\sqrt{\frac{9,83}{9,83+85}}=\mathbf{0 , 3 2}
\end{aligned}
$$

Setelah mengetahui nilai C, selanjutnya memperoleh nilai koefisien kontingernsi C maksimum adalah dengan:

$$
\begin{gathered}
C_{\text {maks }}=\sqrt{\frac{m-1}{m}} \\
C_{\text {maks }}=\sqrt{\frac{2-1}{2}}=\mathbf{0 , 7 0}
\end{gathered}
$$

Setelah nilai koefisien kontingensi C maksimum diketahui, langkah selanjutnya adalah untuk mengetahui derajat hubungan asosiasi dengan cara:

$$
\mathrm{C}_{\text {maks }}-\mathrm{C}=0,32-0,70=\mathbf{0 , 3 8}
$$

Derajat hubungan asosiasi jenis kelamin dengan frekuensi menerima pesan sebesar 0,38. Untuk melihat keterkaitannya peneliti menggunakan asumsi Cramer, makin dekat harga $\mathrm{C}$ kepada Cmaks makin besar derajat derajat asosiasi antar faktor (Sudjana, 2002). Dengan hasil hitung jarak harga $C$ kepada Cmaks sebesar 0,38 maka dapat diindikasikan bahwa jenis kelamin memiliki keterkaitan moderat dengan frekuensi menerima pesan penagihan koleksi dari whatsapp Perpustakaan Kemendikbud.

Tabel 7. Jenjang pendidikan dengan redaksi pesan dimengerti

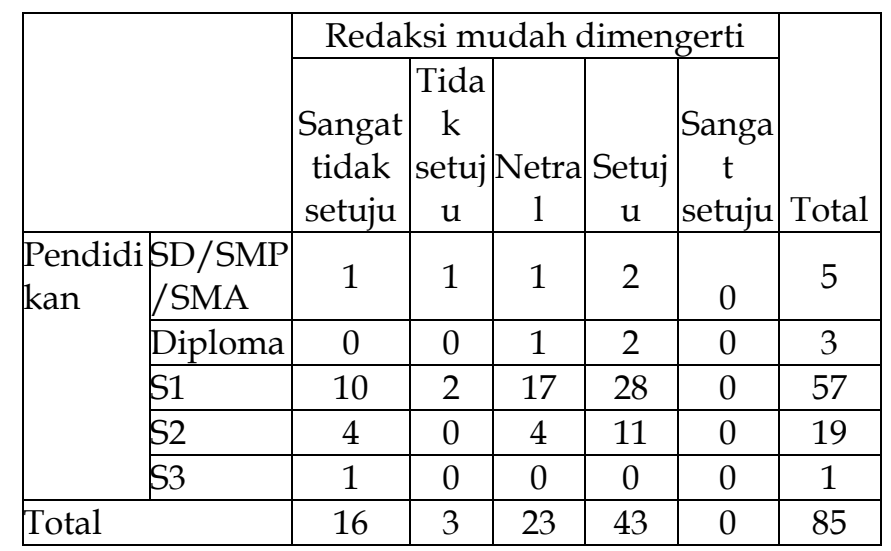

Berdasarkan tabel 7 dapat dilihat tanggapan responden mengenai redaksi pesan penagihan koleksi menunjukkan bahwa dari 85 responden terdapat 16 responden menyatakan sangat tidak setuju 3 responden menyatakan tidak setuju, 23 responden menyatakan netral, 43 responden menyatakan setuju, dan 0 responden menyatakan sangat setuju. Dominasi tanggapan responden menyatakan setuju bahwa redaksi pesan penagihan koleksi mudah dimengerti. Dengan kata lain redaksi atau tata bahasa pesan penagihan koleksi Perpustakaan Kemendikbud yang dikirim melalui whatsapp mudah dimengerti oleh penerimanya (anggota). 
Table 2 Hasil uji chi-kuadrat

\begin{tabular}{|l|r|r|r|}
\hline & & & $\begin{array}{r}\text { Asymp. } \\
\text { Sig. (2- } \\
\text { sided) }\end{array}$ \\
\hline $\begin{array}{l}\text { Pearson Chi- } \\
\text { Square }\end{array}$ & $\begin{array}{r}10.639 \mathrm{a} \\
\text { Likelihood Ratio }\end{array}$ & 12 & .560 \\
\hline $\begin{array}{l}\text { Linear-by-Linear } \\
\text { Association }\end{array}$ & .052 & 12 & .703 \\
\hline N of Valid Cases & 85 & & .819 \\
\hline
\end{tabular}

Dari tabel 8, hasil uji Chi-Kuadrat antara jenjang pendidikan dengan kemudahan redaksi pesan untuk dimengerti menunjukkan $\alpha=0,5$ dengan derajat kepercayaan $95 \%$ dan $\mathrm{df}=16(\mathrm{df}$ awal 16, df hitung 12 namun perhitungan menggunakan df awal). Chi-kuadrat tabel sebesar 26,3 dan Chi-kuadrat hitung sebesar 10,63. Dengan demikian Chikuadrat hitung kurang dari dari Chikuadrat tabel 10,63 < 26,3 maka tidak terdapat hubungan antara jenjang pendidikan dengan kemudahan redaksi pesan untuk dimengerti.

\section{Hubungan Kajian Intensitas Pesan dengan Penghindaran Sanksi Administratif}

Berdasarkan hasil pengujian statistik menggunakan rumus Pearson Product Moment dengan derajat kepercayaan 95\% diperoleh hasil nilai koefisien korelasi sebesar 0,225 yang menunjukkan keeratan hubungan intensitas pesan penagihan koleksi melalui akun whatsapp Perpustakaan Kemendikbud memiliki hubungan rendah. Hasil thitung 2,11 lebih besar dari ttabel 1,66342, maka intensitas pesan penagihan koleksi melalui akun whatsapp Perpustakaan Kemendikbud berhubungan signifikan dengan penghindaran sanksi administratif.

Banyaknya informasi yang diperoleh seseorang akan bisa menghubungkan bahkan juga mampu mengabstraksikan sesuatu (Mulyana, 2002). Hasil dari abstraksi tersebut merupakan sebuah efek dari stimulus yang diterima. Khalayak yang menerima pesan dari media massa cenderung akan mengalami proses perubahan, baik sikap, pendapat, maupun tingkah laku (Effendy, 1993).

Pada penelitian ini, intensitas pengiriman pesan penagihan koleksi yang dikirim melalui media sosial whatsapp Perpustakaan Kemendikbud secara personal dari setiap peminjaman koleksi yang dilakukan kepada anggota. Hal tersebut sebagai bentuk pencegahan perilaku penyalahgunaan waktu peminjaman koleksi menjadi stimulus yang akan diterima oleh anggota yang selanjutnya menjadi penentuan sikap anggota yaitu penghindaran sanksi administratif. Intensitas disini termasuk didalamnya adalah waktu pengiriman pesan dan frekuensi pengiriman pesan. Hal tersebut berpengaruh terhadap sikap yang diputuskan oleh anggota sebagai penerima pesan. Dilihat dari hasil keeratan hubungan yang rendah, dapat dikatakan bahwa terdapat hal yang kurang pada indikator intensitas.

Intensitas pengiriman koleksi yang diterima pemustaka dari setiap peminjaman masih kurang menentukan terhadap sikap pemustaka untuk menghindari sanksi administratif jika melanggar batas peminjaman koleksi. Berdasarkan hasil observasi peneliti pada Agustus 2017, peneliti menemukan bahwa belum ada penetapan waktu pengiriman pesan yang konsisten (pagi, siang, sore atau malam hari). Waktu menggunakan 
media sosial setiap individu dalam hal ini pemustaka pun memiliki intensitas yang berbeda-beda baik durasi ataupin frekuensinya. Berikut penjelasan mengenai frekuensi dan durasi oleh Ardianto, Komalah, Karlina (2007: 186).

"Frekuensi pengguna media mengumpulkan data khalayak tentang berapa kali sehari sesorang menggunakan media dalam satu minggu, berapa kali seminggu seseorang menggunakan media dalam satu bulan serta berapa kali dalam sebulan seseorang menggunakan media dalam satu tahun. Sedangkan pengukuran variabel-variabel durasi penggunaan media adalah menghitung berapa lama khalayak bergabung dengan satu media, atau berapa lama khalayak mengikuti suatu program."

Berdasarkan penjelasan di atas dapat dilihat bahwa waktu pengiriman pesan juga membutuhkan survey frekuensi serta durasi pemakaian media sosial oleh penggunanya. Dengan beragamnya pemustaka di Perpustakaan Kemendikbud baik pekerjaan dan usia, dibutuhkan waktu pengiriman yang tepat agar pesan dapat dibaca dan direspon kembali oleh penerima pesan tersebut.

Berbeda dengan konsistensi waktu pengiriman tersebut, waktu pengiriman pesan sehari sebelum batas waktu peminjaman sudah cukup konsisten dilihat dari data kuisioner, hal ini juga diperkuat dengan pernyataan admin whatsapp Perpustakaan Kemendikbud:

"Kalau ketentuan waktu gak ada yang penting setiap hari, mau siang/pagi terserah aja. Pesan itu ada dua, satu pesan mengingatkan sebelum telat yang kedua setelah telat. Biasanya sih kurang dari satu hari." (Ibu Wati, dalam Chat Penulis. 14 Juli 2017).

Dari pembahasan di atas dapat dilihat bagaimana intensitas pesan penagihan koleksi yang dikirim melalui media sosial whatsapp Perpustakaan Kemendikbud memiliki hubungan signifikan dengan penghindaran sanksi administratif, namun dengan tingkat keeratan hubungan yang rendah. Artinya intensitas pengiriman pesan penagihan koleksi melalui media sosial whatsapp tidak sepenuhnya menjadi faktor penentu sikap pemustaka untuk menghindari sanksi administratif namun memiliki hubungan walaupun dalam tingkat rendah.

\section{Hubungan Kajian Isi Pesan dengan Penghindaran Sanksi Administratif}

Berdasarkan hasil pengujian statistik menggunakan rumus Pearson Product Moment dengan derajat kepercayaan 95\% diperoleh hasil nilai koefisien korelasi sebesar 0,006 yang menunjukkan keeratan hubungan intensitas pesan penagihan koleksi melalui akun whatsapp Perpustakaan Kemendikbud memiliki hubungan sangat rendah. Hasil thitung 0,076 kurang dari ttabel 1,66342, maka isi pesan penagihan koleksi melalui akun whatsapp Perpustakaan Kemendikbud tidak berhubungan signifikan dengan penghindaran sanksi administratif.

\section{Komunikasi adalah proses} penyampaian suatu pesan oleh seseorang kepada orang lain untuk memberitahu atau mengubah sikap pendapat atau perilaku, baik langsung secara lisan, maupun tidak langsung melalui media (Effendy, 2003 : 79). Media menjadi perantara penyampaian pesan yang disampaikan. Agar pesan yang disampaikan dapat diterima dengan baik, maka dibutuhkan isi pesan yang baik pula karena "isi media menentukan sebagian besar dari hasil" (Sendjadja, 2007).

Dilihat dari hasil penelitian didapat bahwa kelengkapan, kerincian dan tata bahasa isi pesan penagihan koleksi 
melalui media sosial whatsapp Perpustakaan Kemendikbud sudah baik. Dimana pesan tersebut sudah cukup membuat pemustaka untuk segera memperpanjang maupun mengembalikan koleksi. Namun pesan tersebut kurang membuat pemustaka untuk peduli dengan sanksi administratif yang akan didapatkan oleh pemustaka jika terlambat mengembalikan koleksi tersebut. Sedangkan tujuan dari pengiriman pesan penagihan koleksi sendiri adalah agar penerima pesan sadar akan kesalahannya dan segera mengembalikan koleksi pada waktu yang ditentukan.

Dari pembahasan di atas dapat dilihat bagaimana isi pesan penagihan koleksi yang dikirim melalui media sosial whatsapp Perpustakaan Kemendikbud memiliki hubungan yang sangat rendah dengan sikap pemustaka untuk menghindari terkena sanksi administratif jika terlambat mengembalikan koleksi. Artinya isi pesan penagihan koleksi Perpustakaan Kemendikbud yang dikirim melalui media sosial whatsapp sangat kurang dalam menjadi faktor penentu sikap pemustaka untuk menghindari sanksi administratif namun memiliki hubungan walaupun dalam tingkat rendah.

\section{Hubungan Kajian Daya Tarik Pesan dengan Penghindaran Sanksi Administratif}

Berdasarkan hasil pengujian statistik menggunakan rumus Pearson Product Moment dengan derajat kepercayaan 95\% diperoleh hasil nilai koefisien korelasi sebesar 0,655 yang menunjukkan keeratan hubungan daya tarik pesan penagihan koleksi melalui akun whatsapp Perpustakaan Kemendikbud memiliki hubungan kuat dengan penghindaran sanksi administratif. Hasil thitung 7,956 lebih besar dari ttabel 1,66342, maka daya tarik pesan penagihan koleksi melalui akun whatsapp Perpustakaan Kemendikbud berhubungan signifikan dengan penghindaran sanksi administratif.

Daya tarik merupakan appeals pesan yang mengacu pada motif psikologis yang mengandung seperti pesan rasional, emosional, dan daya tarik akan ganjaran tertentu (Liliweri, 1992: 76). Daya tarik dalam penelitian ini adalah daya tarik pesan penagihan koleksi yang dikirim menggunakan akun whatsapp Perpustakaan Kemendikbud. Penggunaan jenis media dipilih menurut jenis pesan yang dikirim, banyaknya pemakai dan intensitas pemakaian media tersebut. Media sosial whatsapp memiliki pengguna yang tinggi di Indonesia, menurut situs we are sosial tahun 2016, whatsapp berada pada urutan ketiga pengguna terbanyak di Indonesia. Begitu pula di Perpustakaan Kemendikbud yang rata-rata anggotanya memiliki akun whatsapp. Maka adalah benar ketika Perpustakaan memilih penggunaan media sosial whatsapp sebagai media penyampaian pesan penagihan koleksi yang sebelumnya dikirim menggunakan email.

Teknologi ini sebelumnya sudah dikenal dengan nama Instan Messaging (IM) dalam web 2.0 yang merupakan fasilitas cepat untuk pengguna yang menyediakan chat reference, dimana terdapat komunikasi dua arah antara pemustaka dengan pustakawan (Maness, 2008). Komunikasi ini memungkinkan pemustaka untuk berkomunikasi seperti tatap muka dengan pustakawan hanya saja melalui media sosial dalam hal ini whatsapp. 
Jenis pesan yang dikirim adalah berupa teks pesan penagihan yang dikirim secara personal kepada anggota. Dari hasil penelitian dapat dilihat bahwa dengan penggunaan media sosial whatsapp, pengguna merasa terbantu mengingat koleksi mana yang harus dan belum mereka kembalikan. Hal tersebut dapat dikategorikan pada aspek rasional pada indikator daya tarik pesan. Kesadaran penerima akan pesan berarti pesan tersebut mengandung pesan emosional. Daya tarik penggunaan media whatsapp sudah menjadi poin utama dalam indikator ini, namun sayangnya kurangnya rasa sadar penerima akan ganjaran atau sanksi administratif yang akan mereka dapatkan jika melanggar merupakan hal yang menjadi pokok perhatian dalam indikator ini.

Dari pembahasan di atas dapat dilihat bagaimana daya tarik pesan penagihan koleksi yang dikirim melalui media sosial whatsapp Perpustakaan Kemendikbud memiliki hubungan yang kuat dengan sikap pemustaka untuk menghindari terkena sanksi administratif jika terlambat mengembalikan koleksi. Artinya daya tarik pesan penagihan koleksi Perpustakaan Kemendikbud yang dikirim melalui media sosial whatsapp sudah cukup kuat dalam menjadi faktor penentu sikap pemustaka untuk menghindari sanksi administratif.

Intensitas pengiriman koleksi yang diterima pemustaka dari setiap peminjaman masih kurang menentukan terhadap sikap pemustaka untuk menghindari sanksi administratif jika melanggar batas peminjaman koleksi di Perpustakaan Kemendikbud. Berdasarkan hasil observasi peneliti pada Juli 2017, peneliti menemukan bahwa belum ada penetapan waktu pengiriman pesan yang konsisten (pagi, siang, sore atau malam hari). Waktu menggunakan media sosial setiap individu dalam hal ini pemustaka pun memiliki intensitas yang berbedabeda baik durasi ataupin frekuensinya. Menurut Ardianto, Komalah, Karlina (2007: 186) untuk frekuensi pemustaka media dapat dilihat dari berapa kali pemakaian media sosial dalam beberapa waktu (hari/minggu/bulan).

Berdasarkan penjelasan di atas dapat dilihat bahwa waktu pengiriman pesan juga membutuhkan survey frekuensi serta durasi pemakaian media sosial oleh pemustakanya. Dengan beragamnya pemustaka di Perpustakaan Kemendikbud baik pekerjaan dan usia, dibutuhkan waktu pengiriman yang tepat agar pesan dapat dibaca dan direspon kembali oleh penerima pesan tersebut.

Selanjutnya, kelengkapan, kerincian dan tata bahasa isi pesan penagihan koleksi melalui media sosial whatsapp Perpustakaan Kemendikbud sudah baik. Di mana pesan tersebut sudah cukup membuat pemustaka untuk segera memperpanjang maupun mengembalikan koleksi. Namun pesan tersebut kurang membuat pemustaka untuk peduli dengan sanksi administratif yang akan didapatkan oleh pemustaka jika terlambat mengembalikan koleksi tersebut. Sedangkan tujuan dari pengiriman pesan penagihan koleksi sendiri adalah agar penerima pesan sadar akan kesalahannya dan segera mengembalikan koleksi pada waktu yang ditentukan. Media menjadi perantara penyampaian pesan yang disampaikan. Agar pesan yang disampaikan dapat diterima dengan baik, maka dibutuhkan isi pesan yang baik pula karena "isi media menentukan sebagian besar dari hasil" (Sendjadja, 2007).

Indikator daya tarik merupakan appeals pesan yang mengacu pada motif psikologis yang mengandung seperti pesan rasional, emosional, dan daya tarik 
akan ganjaran tertentu (Liliweri, 1992: 76). Penggunaan media sosial whatsapp dalam pengiriman pesan penagihan koleksi merupakan inovasi baru dalam kajian ini. Teknologi ini sebelumnya sudah dikenal dengan nama Instan Messaging (IM) dalam web 2.0 yang merupakan fasilitas cepat untuk pemustaka yang menyediakan chat reference, dimana terdapat komunikasi dua arah antara pemustaka dengan pustakawan (Maness, 2008). Komunikasi ini memungkinkan pemustaka untuk berkomunikasi seperti tatap muka dengan pustakawan hanya saja melalui media sosial dalam hal ini whatsapp.

Jenis pesan yang dikirim adalah berupa teks pesan penagihan yang dikirim secara personal kepada anggota. Dari hasil penelitian dapat dilihat bahwa dengan pemustakaan media sosial whatsapp, pemustaka merasa terbantu mengingat koleksi mana yang harus dan belum mereka kembalikan. Hal tersebut dapat dikategorikan pada aspek rasional pada indikator daya tarik pesan. Kesadaran penerima akan pesan berarti pesan tersebut mengandung pesan emosional. Daya tarik pesan media whatsapp sudah menjadi poin utama dalam indikator ini, namun sayangnya kurangnya rasa sadar penerima akan ganjaran atau sanksi administratif yang akan mereka dapatkan jika melanggar merupakan hal yang menjadi pokok perhatian dalam indikator ini.

\section{KESIMPULAN}

Sesuai dengan pemaparan hasil penelitian, dapat disimpulkan bahwa intensitas pesan penagihan koleksi yang dikirim melalui media sosial whatsapp memiliki hubungan signifikan dengan sikap pemustaka terhadap tata tertib perpustakaan. Dalam waktu pengiriman pesan, Perpustakaan Kemendikbud belum memiliki penetapan waktu pengiriman pesan yang konsisten (pagi, siang, sore atau malam hari).

Isi pesan penagihan koleksi yang dikirim melalui media sosial whatsapp tidak berhubungan signifikan dengan sikap pemustaka terhadap tata tertib perpustakaan. Walaupun isi pesan penagihan koleksi sudah lengkapan, rincian dan dengan tata bahasanya sudah baik, namun pesan tersebut tidak membuat pemustaka untuk peduli dengan sanksi administratif yang akan didapatkan oleh pemustaka jika terlambat mengembalikan koleksi tersebut.

Daya tarik pesan penagihan koleksi yang dikirim melalui media sosial whatsapp memiliki hubungan signifikan dengan sikap pemustaka terhadap tata tertib perpustakaan. Penggunaan media sosial whatsapp sebagai media pengiriman pesan penagihan koleksi lebih efektif karena sudah menjadi media komunikasi sehari-hari dan dikirim secara personal kepada penerimanya.

\section{DAFTAR PUSTAKA}

Ardianto, E., Komala, L \& Karlinah, S. (2007). Komunikasi Massa Suatu Pengantar. Bandung: Simbiosa Rekatama Media.

Azwar, S. (2012). Sikap Manusia: Teori dan Pengukurannya. Yogyakarta: Pustaka Pelajar.

Balea, J. (2016). The latest stats in web and mobile in Indonesia (INFOGRAPHIC). Retrieved from https://www.techinasia.com/ind onesia-web-mobile-statistics-weare-sosial

Bungin, B. (2004). Metodologi Penelitian Kuantitatif: Komunikasi, Ekonomi, dan Kebijakan Publik 
Serta Ilmu-Ilmu Sosial Lainnya (Kencana). Jakarta.

Damayanti, D., Sukaesih, S., \& Rainathami, H. (2015). Upaya Pencegahan Penyalahgunaan Koleksi Perpustakaan Kemendikbud. Jurnal Kajian Informasi \& Perpustakaan, 3(2), 147-154.

doi:http:/ / dx.doi.org/10.24198/jk ip.v3i2.9977

Kurniasih, N. (2015). Optimalisasi Penggunaan Media Sosial untuk Perpustakaan. Retrieved from https:/ / www.academia.edu/1728 9773/Optimalisasi_Penggunaan_ Media_Sosial_untuk_Perpustakaa $\mathrm{n}$

Liliweri, A. (1992). Dasar-Dasar Komunikasi Periklanan. Bandung: PT. Citra Aditya Bakti.

Maness, J. M. (2008). Teori Library 2.0: Web 2.0 dan Dampaknya terhadap Perpustakaan*. Retrieved September 2, 2017, from http:/ / www.perpusnas.go.id/ma gazine/teori-library-20-web-20-

dan-dampaknya-terhadapperpustakaan/

Riduwan \& Sunarto. (2012). Pengantar Statistika untuk Penelitian: Pendidikan, Sosial, Ekonomi, Komunikasi, dan Bisnis. Bandung: Alfabeta.

Prijana, Winoto, Y. dan Yanto, A. (2016). Metode penelitian kuantitatif Ilmu Perpustakaan dan Informasi. Bandung: Unpad Press.

Rusmana, A. (2015). Penipuan dalam Interaksi Melalui Media Sosial (Kasus Peristiwa Penipuan melalui Media Sosial dalam Masyarakat Berjejaring). Jurnal Kajian Informasi \& Perpustakaan, $3(2)$, 187-194. doi:http:/ / dx.doi.org/10.24198/jk ip.v3i2.9994
Sendjadja, S. D. (2002). Pengantar Komunikasi. Jakarta: Pusat Penerbitan Universitas Terbuka.

Siregar, S. (2011). Statistika Deskriptif untuk Penelitian: Dilengkapi perhitungan manual dan aplikasi SPSS versi 17. Jakarta: Rajawali Pers.

Tustiver, A. \& Nelisa, M. (2013). FaktorFaktor Peminjaman Tidak Sah (Unauthorized Borrowing) Bahan Pustaka di Kantor Arsip Perpustakaan dan Dokumentasi Kota Padang. IPI, 2(1), 20-26. Retrieved from http:/ / download.portalgaruda.or $\mathrm{g} /$ article.php?article $=101340 \& v a l$ $=1516$ 